\title{
P 193
}

運動時の血圧変動に影響を及注す因子

\author{
楖司純子" 、須田研一郎 ${ }^{21}$ 、土屋五郎 ${ }^{21}$ \\ 1) 三菱重工(株)神户造船所、衙生課 ${ }^{2)}$ 三菱神戸病院、内科
}

(はじめに)当所では、定期键庿 診断において異常な

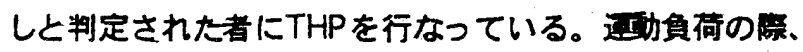
血压をモニターし安全に実施できるようにしているが、 なかに血圧が大幅に上曾する者を認める. Kirchoffは、

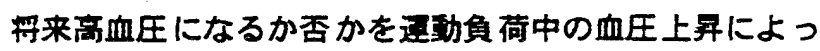
てある程度知ることかできると報告している。また、荒 丽は、正常血压者でも高血圧素因のあるものは、王動負 荷において有意な血在上军を䛱めるとしている。今回、 我々は、量動負荷中血压上界を示す者のハックッグラン

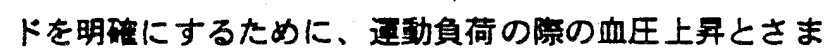
さまな因子との関速を検討した。

(方法)対象者は、3カ月以内の定期健康診断で異常な しと診断されたものて、現在、治英を行なってない男子 社胃473名(血圧は、140/90以下)である。当日の血压 を安静座位に朐定した後、エルコメーターにより 70\%HRの正峌負荷((220一年䪭) x 0.7)を実施した。負 荷は、25w．50w.75w．100w.125wと3分毎に段暏 的に強くなり、披碤者の心拍数か、目顺心拍数に逵する と自较的に角荷か，像止されるようプログラムされてい る。負荷中の血圧は、自動血压計にて1分おきに测定さ れる。険討する因子は、以下の8項目である。1、当日の 負荷前の安静座位血压、2、仕重内容(1、整務職 2、現

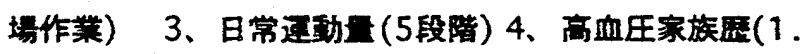

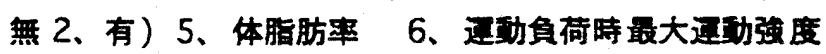
(Met) 7、最大酸泰损取年 8、エゴグラム $(X=N P-C P$, $Y=F C-A C と し(X)(Y)$ の数值で分颣、type1; $(-)(+)$ か $\supset$ A $>$ FC, type2; $(-)(+)$ か A $\triangle$ FC, type3; $(-)(-)$, type4; $(+)(+)$, type5; $(+)(-))$ 以上の因子において 年代別 (20才代、30才代、40才以上60才以下)に多变量 解析を行なった，解析方法は、数是化理辣2類、およひ 多至ロジステイック モテルを用い、基準変数；角荷時

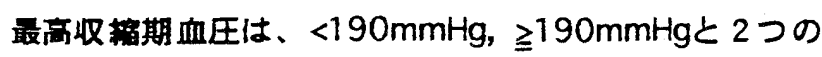
グルーブに分けた.

(蛣果)1)当日の負荷前の安静座位血压、体脂肪重 。 垔勤負荷時最大遇轨強度(Met) は、20才代、40才以上

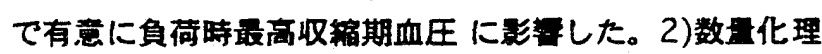

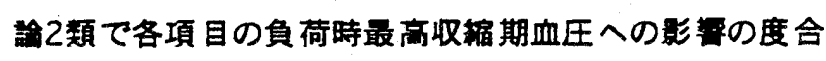
を調べると、上位は、当日の負荷前の安静座位血圧、体

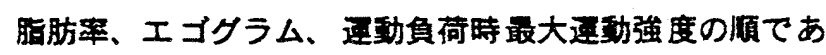
るか、エゴグラムのなかでもtype1,type2,type3か、負

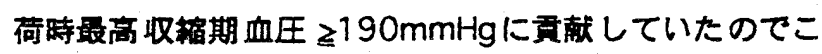
の3typeの多至ロジスティックモテル解析を行なったと ころ、40才以上でtype2か、有意に影福した。

（まとめ）1）当日体調が瑟かったり、睡眠不足がる

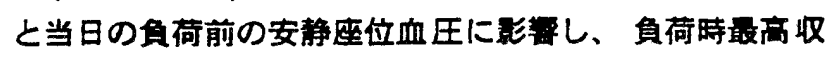
桯期血区を上年させている可能性がる。2)エコグラム において type 1, type2,は、CPANP、かつFC>ACて、ス トレスか、たまりにくいタイブであるか、とりわけ type2は、自己主張ができ、共任感がつよく明るく健康 的で理想のタイプである.40才以上でtype2の者に負荷

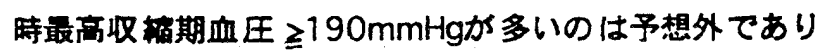
さらに梌討を要する。3)従来の報告と異なり高血匠家族 㢄との関連は、哭められなかった。

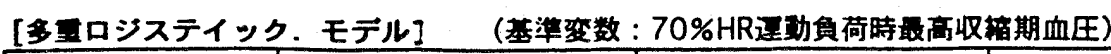

\begin{tabular}{|c|c|c|c|c|c|c|}
\hline & 20才代 & $(n=206)$ & 30才代 & $(n=102)$ & 40才代 & $(n=165)$ \\
\hline & F鉜 & オッス比 & F位 & オッズ比 & F僆 & オッス比 \\
\hline 当日負荷前収摍血压 & $15.288^{* \star}$ & $1.087 \mathrm{~b}$ & 0.973 & 1.043 & $15.171^{\star \star}$ & $1.156 \mathrm{~b}$ \\
\hline 仕事内容 & 0.008 & 1.041 & 0.021 & 0.876 & 0.071 & 1.158 \\
\hline 日常国杵量 & 0.327 & 0.827 & 0.133 & 0.782 & 0.205 & 1.191 \\
\hline 高血压家族厢 & 0.261 & 1.269 & 0.003 & 1.045 & 0.102 & 1.025 \\
\hline 体脂肪案 & 4.452 * & $1.144 \mathrm{a}$ & 0.001 & 1.003 & $4.083^{*}$ & $1.212 \mathrm{a}$ \\
\hline 真荷最大而勤強度 & 8.442 * & $2.757 \mathrm{a}$ & 1.465 & 2.188 & $5.903 *$ & $3.327 \mathrm{a}$ \\
\hline 浱大酸泰摄取旦 & 3.869 & 0.893 & 1.742 & 0.838 & 1.621 & 0.895 \\
\hline エコグラム type1 & 2.011 & 2.633 & 1.283 & 0.366 & 2.184 & 5.255 \\
\hline type2 & 0.841 & 1.755 & 0.211 & 0.634 & 7.984 * & $30.344 \mathrm{~b}$ \\
\hline type3 & 0.472 & 1.625 & 3.371 & 0.103 & 1.466 & 3.781 \\
\hline
\end{tabular}

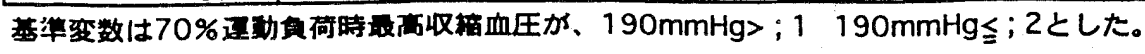

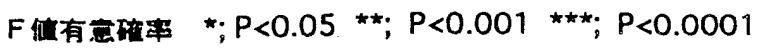

オッス比 a; $95 \%$ 䁬赖 b; 99\%倍賴 